\title{
Impact of Students' Exposure to Electronic Media Facilities in Their Homes on Parental Involvement in Management of Students' Discipline in Public Day Secondary Schools in Kenya
}

\author{
Lydia Mbaki Musau
}

Doctor of Education Degree (Ed. D) in Educational Administration Candidate, School of Education, University of Nairobi, Nairobi, Kenya

Ursulla Okoth, Senior lecturer Phylisters Matula, Lecturer

Department of Educational Administration and Planning, Nairobi, Kenya

Doi: 10.19044/esj.2017.v13n31p202 URL:http://dx.doi.org/10.19044/esj.2017.v13n31p202

\begin{abstract}
Students' exposure to electronic media facilities and lack of parental supervision has led to indiscipline among students globally. The purpose of this study was to investigate the impact of students' exposure to electronic media facilities in their homes on parental involvement in management of students' discipline in public day secondary schools in Kitui County, Kenya. The hypothesis was: there is no significant difference in means between students' exposure to electronic media facilities and parental involvement in management of students' discipline. The sample consisted of 70 principals, 86 Form three class teachers and 354 Form three students. The instruments were questionnaires and focus group discussions. A pre- test was used to validate the questionnaires while a test-re-test method was used to determine reliability. Instruments reliability coefficients were 0.78 for head teachers, 0.75 for class teachers and 0.82 for students' questionnaires. Descriptive and inferential statistics were utilized for data analysis while the level of significance was set at alpha $=0.05$. Based on the results of ANOVA, F (4, $146)=85.548, P=0.087$, the hypothesis was accepted. It was concluded that students' exposure to electronic media facilities influenced parental involvement in management of students' discipline although this was not significant. It was recommended that parents should monitor and control the use of electronic media facilities by their children at home to control students' discipline at school. This paper was drawn out from a study conducted in the year 2016 and 2017 in Kitui County, Kenya.
\end{abstract}


Keywords: Impact, students' exposure, electronic media, parental involvement, discipline management, public day secondary schools, Kitui County, Kenya

\section{Introduction}

Deterioration of discipline among students is an existing problem affecting secondary schools globally. Findings of studies done in Australia and Singapore indicate that students' indiscipline in schools is caused by acquisition of adverse information accessed from the electronic media facilities such as computers, cell phones and televisions in their homes (Stewart, 2004; Esther \& Cheng,1999). A study by Lin and Pao (2011) revealed that most students in Taiwan prefer playing at computer internet coffee shops where they stay for a long time and copy unbecoming behaviors since they are unable to select the useful information.

Saleem and Anderson (2012) observed that students' exposure to media violence causes aggressive behavior. Gould and Ward (2015) supports this view by asserting that children who are exposed to violence in South Africa are more likely to be anxious and depressed and lack concentration at school. When conducting a study to establish the perceived home factors contributing to violent behavior among public secondary school students in Kenya, Poipoi, Agak and Kabuka (2011) found that students' exposure to violent films and movies and low level of home supervision lead to violence in schools.

Block (2008) asserts that there is a rising concern in America about excessive use of internet by adolescents which leads to wastage of time, feelings of depression when access to computer is not available, lying and social isolation. Tayie, Jacquinot-Delaunay, Carlsson, and Tornero (2008) observes that many parents, teachers and policy-makers in France are concerned about the negative influence of harmful media content accessed by students from electronic gadgets in their homes. According to Anderson, Berkowitz, Donnerstein, Huesmann, Johnson, Linz, Malamuth and Wartella (2003), most of the attempts that have been made to reduce children's media exposure in American homes have failed.

Omangi (2016) reported that students in more than 130 schools in Kenya went on rampage across the country causing unrests after sharing information on social media during the second term of the year 2016 leading to massive destruction of property. However, John (2013) says that some media content influences the students positively. For instance, Light (2009) observed that students in Turkey and India were able to complete their homework without the assistance of their parents through the use of internet research. 
Despite the government's efforts to improve management of students' discipline by establishing the Network, Security and Access Policy, ICT Policy in Education and policy on passwords, indiscipline among students has been worsening. The Purpose of this study was to investigate the impact of students' exposure to electronic media facilities at home on parental involvement in management of students' discipline in public day secondary schools in Kitui County. The study was guided by the following null hypothesis: there is no significant difference in means between students' exposure to electronic media facilities and parental involvement in management of students' discipline. The specific objectives were:

1. Determine the extent to which students' acquisition of negative information from electronic media facilities in their homes influence their discipline at school.

2. Assess the impact of students' exposure to electronic media on their discipline.

3. Establish strategies that could be used by parents to control students' use of electronic media at home to improve their behavior at school.

\section{Methodology}

The ex-post-facto research design was adopted. The design was deemed as appropriate for this study since it helped to investigate the relationship that already exist between parents' exposure of students to electronic media facilities and parental involvement in management of students' discipline in public day secondary schools. Random sampling technique was used to obtain a sample of 70 public day secondary schools. The sample comprised 70 head teachers selected by census sampling. Stratified proportionate random sampling was used to select 86 Form three class teachers and 354 Form three students. Purposive sampling method was used to select 10 Form three students from three of the participating schools to participate in the focus group discussions.

The instruments were questionnaires and focus group discussions. A pre- test was used to validate the questionnaires while reliability was ascertained through a test-re-test method. Instruments reliability coefficients were 0.78 for head teachers and 0.75 for class teachers' questionnaires. Focus group discussions with groups of students were conducted using a focus group interview guide containing open ended items for collaboration of responses. One Way Analysis of Variance (ANOVA) was used to compare means and standard deviations between parents' exposure of students to electronic media facilities and parental involvement in management of students' discipline. The significance level was set at alpha $=0.05$. Data was analyzed by use of descriptive and inferential statistics. 


\section{Results}

\section{Questionnaires return rate}

The questionnaires were administered on principals, class teachers and students. The results are presented in Table 1.

Table 1: Questionnaires return rate

\begin{tabular}{lrcc}
\hline Participant & Sample size & Returned (f) & Percentage \\
\hline Principals & 70 & 70 & $100 \%$ \\
Class teachers & 86 & 80 & $93 \%$ \\
Students & 354 & 336 & $95 \%$ \\
\hline
\end{tabular}

The results indicate that the questionnaire return rate was $100 \%$ from the head teachers, $93 \%$ from the class teachers and $95 \%$ from the students.

\section{Demographic information}

The principals and class teachers were requested to specify their demographic characteristics including gender and teaching experience. The incorporation of these variables in the study is important since it enabled a clear understanding of the background attributes of the participants.

\section{Gender of participants}

It was important to investigate the gender variable since it helped the researcher to ascertain the proportion of the participants in the study per gender. According to Bosire, Sang, Kiumi and Mungai (2009), female principals are more likely to involve parents in managing students' discipline hence gender determines the way teachers manage students' discipline. The participants were requested to specify their gender. The results are presented in Table 2.

Table 2: Gender of the participants

\begin{tabular}{cllll}
\hline & \multicolumn{2}{c}{ Head teachers } & \multicolumn{2}{c}{ Class Teachers } \\
\hline & F & \% & F & \% \\
\hline Male & 41 & 58.6 & 50 & 62.5 \\
Female & 29 & 41.4 & 30 & 37.5 \\
\hline Total & $\mathbf{7 0}$ & $\mathbf{1 0 0 . 0}$ & $\mathbf{8 0}$ & $\mathbf{1 0 0 . 0}$ \\
\hline & Key: F=Frequency & $\%=$ percentage
\end{tabular}

The results show that majority $(58.6 \%)$ of the head teachers and $(62.5 \%)$ of the class teachers were male.

\section{Teaching experience of the participants}

The teachers' experience which is determined by the number of years worked determines how students' discipline is managed. The head teachers and class teachers were asked to indicate the number of years they had served in their current stations. Their working experience helped to 
determine their exposure to students' disciplinary issues. The findings are presented in Table 3.

Table 3: Teaching experience of the participants

\begin{tabular}{ccccc}
\hline & \multicolumn{2}{c}{ Principals } & \multicolumn{2}{c}{ Class Teachers } \\
\cline { 2 - 5 } & $\mathrm{F}$ & $\%$ & $\mathrm{~F}$ & $\%$ \\
\hline Less than 5 years & 12 & 17.1 & 38 & 47.5 \\
$5-9$ & 6 & 8.6 & 22 & 27.5 \\
$10-15$ & 21 & 30.0 & 11 & 13.8 \\
More than 15 years & 31 & 44.3 & 9 & 11.3 \\
\hline Total & 70 & 100.0 & 80 & 100.0 \\
\hline
\end{tabular}

Table 3 shows that majority of the head teachers (44.3\%) had a working experience of more than 15 years followed by $30 \%$ who had worked for $10-15$ years. About $17.1 \%$ of the principals had served for less than five years while $8.6 \%$ had worked for a period of 5-9 years. It was also established that majority $(47.5 \%)$ of the class teachers had worked for less than five years followed by $27.5 \%$ who had worked for a period 5-9 year. About $13.8 \%$ had worked for a period of 10-15 years while the minority $(11.3 \%)$ had served for more than 15 years.

\section{Students' exposure to electronic media facilities at home and parental involvement in management of students' discipline at school}

According to Ilomäki (2008), students find the technology used at home more interesting as they spent their leisure time with friends downloading movies and music from the internet without any educational content. Lauer (2013) notes that prolonged technology use by students is associated with the children's aggression, attention problems and addiction which pose a challenge to school managers in maintaining discipline. The impact of students' exposure to electronic media facilities in their homes was measured on a 5-point range Likert scale using four items related to electronic media. Head teachers were requested to indicate their opinions on how students' exposure to electronic media facilities in their homes influence parental involvement in guiding the learners' behavior. The objective was to determine the impact of parents' exposure of students to electronic media facilities on their participation in guiding the learners' behavior in public day secondary schools.

A rating of "Strongly Agree" was assigned a score of 5; "Agree" was assigned a score of 4; "Undecided" was assigned a score of 3; "Disagree" was assigned a score of 2; "Strongly Disagree" had a score of 1 assigned to it. A weighted mean score was used to interpret the results. A mean score of 3.5 to 5 meant that the head teachers agreed with the item. A mean score of 2.6 to 3.4 meant that the head teachers were undecided or not sure while a 
mean score of 1 to 2.4 meant that they did not agree with the item. The results are shown in Table 4.

Table 4: Head teachers' responses on students' exposure to electronic media and parental

\begin{tabular}{|c|c|c|c|c|c|c|c|c|c|c|c|}
\hline & 5 & 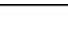 & 4 & & & 3 & & 2 & & 1 & M ear \\
\hline & $F$ & $\%$ & $F$ & & $\mathbf{F}$ & $\%$ & $F$ & $\%$ & $\mathbf{F}$ & $\%$ & \\
\hline \multicolumn{12}{|l|}{$\begin{array}{l}\text { A cquisition of negative } \\
\text { information from electronic } \\
\text { media facilities at home } \\
\text { promote students' } \\
\text { indiscipline in school }\end{array}$} \\
\hline & 30 & 42.9 & 27 & 38.6 & 4 & 5.7 & 6 & 8.6 & 3 & 4.3 & 4.1 \\
\hline \multicolumn{12}{|l|}{$\begin{array}{l}\text { When students are at home, } \\
\text { they use more time for } \\
\text { entertainment on electronic } \\
\text { media than on school work }\end{array}$} \\
\hline & 34 & 48.6 & 20 & 28.6 & 5 & 7.1 & 9 & 12.9 & 2 & 2.9 & 4.0 \\
\hline
\end{tabular}

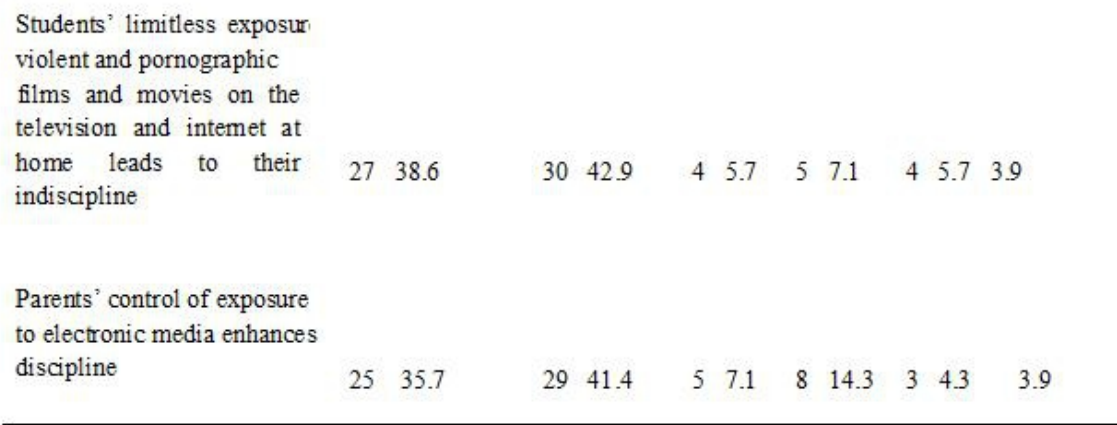

$\mathrm{n}=70$

From Table 4, it was established that acquisition of negative information from electronic media facilities at home promote students' indiscipline in school with the item having a mean score of 4.1. About 42.9 $\%$ of the head teachers strongly agreed and $38.6 \%$ agreed with this statement. Only $4.3 \%$ percent of the principals strongly disagreed and 8.6 percent disagreed with the statement. About $5.7 \%$ of the principals were undecided. The results imply that many parents do not monitor what their children access from the electronic media gadgets in their homes.

The head teachers also indicated that when students are at home, they use more time for entertainment on electronic media than on doing school work with the item posting a mean score of 4.0. Slightly less than half (48.6 $\%$ ) of the head teachers strongly agreed and $28.6 \%$ of them agreed with this 
statement. Only $2.9 \%$ of the principals strongly disagreed and $12.9 \%$ disagreed that students use more time for entertainment when they are at home. About 7.1 percent of the head teachers were had no opinion.

The findings further revealed that time spent by students on internet at home downloading movies, music and chatting distracts students' attention from studies with the item eliciting a mean score of 3.9. About $42.9 \%$ of the head teachers strongly agreed and $38.6 \%$ agreed with this item. Only $5.7 \%$ of the principals strongly disagreed and $7.1 \%$ of them disagreed that electronic media distracts students' attention from their school work. About 5.7 percent of the head teachers had no opinion.

The head teachers were affirmative that parents' control of students' exposure to electronic media enhances discipline with the item posting a mean score of 3.9. About of the $41.4 \%$ of the principals strongly agreed and $35.7 \%$ agreed with this item. Only $4.3 \%$ strongly disagreed and $14.3 \%$ of the principals disagreed that parental involvement enhances students' discipline. About 7.1 percent of the head teachers were not sure whether parents' control of students' exposure to electronic media at home influences the students' discipline at school.

The responses of the head teachers were confirmed by 43 percent of the class teachers who strongly agreed with the opinions of the principals. The results were further confirmed by the responses from the focus group discussions which indicated that uncontrolled exposure of students to the electronic media facilities in their homes adversely affect their discipline. However, it was also established from the focus group discussions that some of the students were not exposed to electronic media facilities at home because their parents could not afford the cost of electronic gadgets due to poverty. Moreover, some rural areas from where the students commuted lacked electricity and internet infrastructure.

\section{Head teachers' responses on students' discipline level}

The head teachers were asked to rate the level of students' discipline in their schools. The results are presented in Table 5.

Table 5: Principals' responses on students' discipline level

Level of indiscipline

Principals

Frequency Percentage

\begin{tabular}{lcc}
\hline High & 5 & 7.1 \\
Moderate & 20 & 28.6 \\
Low & 45 & 64.3 \\
& & \\
\hline Total & $\mathbf{7 0}$ & $\mathbf{1 0 0}$
\end{tabular}


The results show that majority $(64.3 \%)$ of the head teachers indicated that the level of students' discipline was low followed by 28.6 percent of those who indicated that the discipline was moderate. Only $7.1 \%$ of the principals recorded that the students' discipline was high. The results imply that high indiscipline levels exist in secondary schools. The misconduct could be attributable to the students' acquisition of adverse information accessed from electronic media facilities in their homes coupled with lack of parental supervision.

\section{Class teachers' responses on students' discipline level}

The class teachers were also asked to rate the level of students' discipline in their schools. The results are shown in Table 6.

Table 6: Class teachers' responses on students' discipline level

\begin{tabular}{lcc}
\hline Level of indiscipline & \multicolumn{2}{c}{ Class teachers } \\
& Frequency & Percentage \\
\hline High & 7 & 8.8 \\
Moderate & 30 & 37.5 \\
Low & 43 & 53.7 \\
\hline Total & $\mathbf{8 0}$ & $\mathbf{1 0 0}$ \\
\hline
\end{tabular}

Table 6 shows that the responses of class teachers corresponded with those of the principals with slightly more than half of the class teachers $(53.7$ $\%$ ) indicating that the level of students' discipline was low followed by 37.5 percent of them who indicated that the discipline was moderate. Only $8.8 \%$ of the class teachers indicated that the students' discipline was high.

\section{Students' use of the electronic media at home}

The students were requested to indicate the time they spend daily using the internet or watching television when they are at home. The results are presented in Table 7.

Table 7: Students' responses on time they spend daily on electronic media when at home

\begin{tabular}{|c|c|c|}
\hline $\begin{array}{c}\text { Time per day spent by students on electronic } \\
\text { media }\end{array}$ & Frequency & Percentage \\
\hline Less than one hour & 58 & 17.2 \\
\hline 1-2 hours & 92 & 27.4 \\
\hline 2-5 hours & 170 & 50.6 \\
\hline No access to electronic media at home & 16 & 4.8 \\
\hline Total & $\mathbf{3 3 6}$ & $\mathbf{1 0 0 . 0}$ \\
\hline
\end{tabular}

Table 7 indicates that slightly more than half of the students $(50.6 \%)$ stated that they spent 2-5 hours daily on electronic media when they are at 
home followed by $27.4 \%$ of those who recorded that they spent 1-2 hours. Only $17.2 \%$ of the students indicated that they spent $1-2$ hours daily using the internet or watching television. About $16 \%$ of the students indicated that they had no access to electronic media facilities when they were at home.

\section{Impact of students' exposure to electronic media on their discipline}

Cross tabulation was done on students' level of exposure to electronic media against their discipline to determine the relationship between the level of students' exposure to electronic media facilities in their homes and their discipline level. The findings are shown in Table 8.

Table 8: Cross tabulation between students' exposure to electronic media and their discipline level

\begin{tabular}{|c|c|c|c|c|c|c|c|}
\hline \multirow{2}{*}{ Question } & Level of exposure to electronic media & \multicolumn{6}{|c|}{ Students' level of discipline } \\
\hline & & \multicolumn{2}{|c|}{ High } & \multicolumn{2}{|c|}{ Low } & \multicolumn{2}{|c|}{ Total } \\
\hline & & $\mathrm{F}$ & $\%$ & $\mathrm{~F}$ & $\%$ & $\mathrm{~F}$ & $\%$ \\
\hline \multirow{4}{*}{$\begin{array}{l}\text { Influence of } \\
\text { parents' exposure } \\
\text { of students to } \\
\text { electronic media } \\
\text { facilities on } \\
\text { students' } \\
\text { discipline }\end{array}$} & Highly exposed & 3 & 4.3 & 10 & 14.3 & 13 & 18.6 \\
\hline & Moderately exposed & 5 & 7.1 & 6 & 8.6 & 11 & 15.7 \\
\hline & Not exposed & 45 & 64.3 & 1 & 1.4 & 46 & 65.7 \\
\hline & Total & 53 & 75.7 & 17 & 24.3 & 70 & 100 \\
\hline
\end{tabular}

Table 8 shows that the students who were highly exposed to electronic media facilities in their homes had low level of discipline as indicated by $(14.3 \%)$ of the head teachers in comparison to $4.3 \%$ of those who stated that the students were highly disciplined. About $8.6 \%$ of the school principals indicated that the discipline of students who were moderately exposed to electronic media was low in contrast to $7.1 \%$ of those who indicated that the level of students' discipline was high. The study further revealed that the students who were not exposed to electronic media facilities at home were highly disciplined as indicated by the majority $(64.3 \%)$ of the principals in comparison to $1.4 \%$ of those who stated that the level of students' discipline was low. 


\section{Strategies that could be used by parents to control students' use of electronic media at home so as to improve their behavior at school}

The head teachers were asked to suggest strategies that parents could use to control students' use of electronic media at home. A rating of "Strongly Agree" was assigned a score of 5; "Agree" was assigned a score of 4; "Undecided" was assigned a score of 3; "Disagree" was assigned a score of 2; "Strongly Disagree" had a score of 1 assigned to it. A weighted mean score was used to interpret the results. A mean score of 3.5 to 5 meant that the head teachers agreed with the item. A mean score of 2.6 to 3.4 meant that the head teachers were undecided or not sure while a mean score of 1 to 2.4 meant that they did not agree with the item. The results are presented in Table 9.

Table 9: Head teachers' responses on the strategies used by parents to control students' use of electronic media

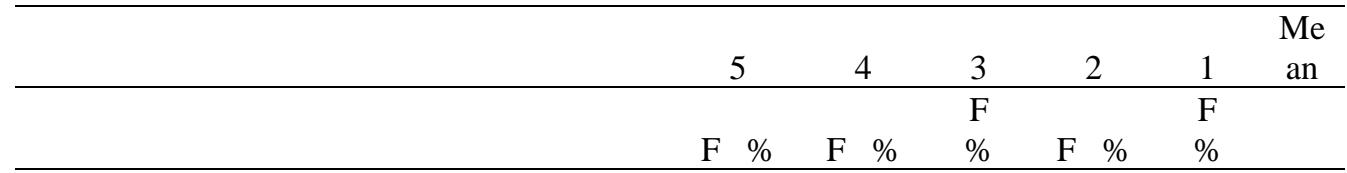

Parents to control the time students spend on media for entertainment

Parents to restrict the content students access from the internet sites

$\begin{array}{cccccc}35 & 22 & 5 & 5 & 3 & \\ 50.0 & 31.4 & 7.1 & 7.1 & 4.3 & 4.2\end{array}$

Avoid students' exposure to electronic

$\begin{array}{cccccc}34 & 23 & 5 & 6 & 2 & \\ 48.6 & 32.9 & 7.1 & 8.6 & 2.9 & 4.1\end{array}$

media violence in the television

$\begin{array}{cccccc}24 & 33 & 4 & 5 & 4 & \\ 34.3 & 47.1 & 5.7 & 7.1 & 5.7 & 4.1\end{array}$

Parents to educate students about unrealistic acts observed in media

$\begin{array}{lllll}24 & 28 & 5 & 10 & 3\end{array}$

\begin{tabular}{llllll}
34.3 & 40 & 7.1 & 14.3 & 4.3 & 3.9 \\
\hline
\end{tabular}

$\mathrm{n}=70$

Table 9 shows that the head teachers agreed that parents' control of the time students spend on electronic media for entertainment at home can help to improve the students' behavior at school with the item having a mean score of 4.2. Majority (50.0 percent of the head teachers and 31.4 percent total, 81.5 percent) agreed that parents should control the time students spend on media for entertainment. Only 4.3 percent and 7.1 percent, total 11.4 percent of them disagreed with the item. About 5.7 percent of the principals were undecided.

The head teachers also indicated that parents' restriction of the content accessed by students from the internet sites can help to improve 
students' behavior at school with the item posting a mean score of 4.1. Majority of the head teachers (48.6 percent and 32.9 percent total 81.5) percent agreed that parents should restrict the content accessed by students from the internet sites. Only 2.9 percent and 8.6 percent total 11.5 percent of them disagreed with the item. About 5.7 percent of them sure about whether restricting the media content accessed by students could improve the students' behavior at school.

There was agreement that avoidance of students' exposure to electronic media violence in the television could help to improve students' discipline at school as indicated by a mean score of 4.1. Majority of the head teachers (47.1 percent and 34.3 percent total 81.4 percent) agreed that parents avoid students' exposure to media violence. Only 5.7 percent and 7.1 percent, total 12.8 percent of them disagreed with the item. About 5.7 percent of the principals had no opinion.

The head teachers were affirmative that education of students about unrealistic acts observed in media can help to improve students' discipline with the item eliciting a mean score of 3.9. Majority of the head teachers (40 percent and 34.3 percent total 74.3 percent) agreed that parents should educate students about unrealistic acts observed in media. Only 4.3 percent and 14.3 percent, total 17.6 percent of them disagreed with the item. About 7.1 percent of them were not sure about the effectiveness of parents' education about unrealistic media acts in tackling students' discipline problems.

\section{Testing the hypothesis}

Analysis of variance (ANOVA) is a collection of statistical models used in analyzing the differences among group means and their associated procedures such as variations among and between groups. One-way ANOVA is used to determine whether there are any statistically significant differences between the means of three or more independent groups. The ANOVA was used to test the following null hypothesis:

Ho: there is no significant difference in means between students' exposure to electronic media facilities and parental involvement in management of students' discipline in public day secondary schools.

The results are presented in Table 10.

Table 10: ANOVA on students' exposure to electronic media facilities at home and parental involvement in management of students' discipline

\begin{tabular}{cccccc}
\hline & $\begin{array}{c}\text { Sum of } \\
\text { Squares }\end{array}$ & Df & Mean Square & F & Sig. \\
\hline Between Groups & 57.877 & 4 & 14.469 & 85.548 & .087 \\
Within Groups & 10.994 & 146 & .169 & & \\
Total & 68.871 & 150 & & & \\
\hline
\end{tabular}


Results in Table 9 show that the $\mathrm{P}$-value $=0.087$ which is more than the significance level of 0.05 . On this basis, the hypothesis was accepted and conclusion made that there is no significant difference in means between parents' exposure of students to electronic media facilities and their involvement in management of students' discipline in public day secondary schools. These results imply that students' exposure to electronic media facilities in their homes may not significantly influence their discipline at school.

The also imply that not all students in the area under study were able to access the electronic media facilities in their homes since their parents were too poor to afford the cost of electronic gadgets. Moreover, most of the day scholars commuted from rural areas where there was no electricity or internet connectivity. These factors hindered he students from accessing the electronic media facilities which could have adversely influenced their behavior. The results are consistent with those of Pearson (2006) who observed that negative media influence alone is not enough to account for students' indiscipline at school. The results also agree with Lavin, Korte and Davies (2010) who asserted that when used appropriately, technology can have a positive impact on students' behavior and perceptions, amount of time they study for exams and their overall attendance to class.

\section{Discussion}

The purpose of this study was to investigate the impact of parents' exposure of students to electronic media facilities on parental involvement in management of students' discipline in public day secondary schools in Kitui County, Kenya. The hypothesis was: there is no significant relationship between students' exposure to electronic media facilities in their homes and parental involvement in management of students' discipline. The questionnaire return rate was 100\% from the head teachers and $93 \%$ from the class teachers implying that it was a very good representation (Mugenda and Mugenda, 2003).

The study revealed that majority $(58.6 \%)$ of the head teachers and $(62.5 \%)$ of the class teachers in public day secondary schools were male. These results can be interpreted to mean that women are under-represented in management of public day secondary schools implying that they are less involved in the management of students' discipline. Onderi and Makori (2013) concur that women are greatly under-represented in management positions in Kenya. The results are supported by Wango, Musomi, and Akinyi (2012) who observed that lack of adequate female role models especially in the rural areas hinders girls' and women's empowerment through education. However, the finding contradicts Article 232 (i) of the Kenya Constitution which accords equal opportunities for appointment, 
training and advancement of men and women at all levels of the public sector (Republic of Kenya, 2010).

The results indicate that there is need for the Teachers Service Commission (TSC) to increase the appointment of female school head teachers and the schools to increase appointment of female class teachers to act as role models for girls. The Ministry of Education came up with the Gender Policy in Education to address the challenge of gender inequality in education in Kenya. The Policy aims at balancing gender during intake of teacher trainees and in deployment of teachers in schools to achieve gender balance and equality in staffing (Republic of Kenya, 2007a).

From the findings, it was established that the highest proportion of the head teachers $(44.3 \%)$ had a working experience of more than 15 years while only 8.6 percent of them had worked for a period of 5-9 years. These results indicate that majority of the principals in public day secondary schools have gained enough experience to manage students' discipline while the less experienced teachers are given the role of class teachers to gain more experience in managing students' discipline before they can be appointed as school heads. Khewu (2012) concurs that the working experience of head teachers determines their exposure to issues of students' discipline. The findings are consistent with Onderi and Makori (2013) who observed that many principals have enough experience to deal with students' issues. They are also in line with the TSC Code of Regulations Section 74 (b) which states that the Commission considers experience in promoting a teacher as set out in the scheme of service (Republic of Kenya, 2006). This implies that the longer the teaching experience of the teachers, the more they are exposed to challenges of managing students' indiscipline.

The findings showed that when students are at home, they use more time for entertainment on electronic media than on doing school work as indicated by a mean score of 4.0 and by majority of the head teachers $(77.2$ $\%)$. The results indicate that the students waste a lot of time on media instead of doing homework meaning that parents do not limit the time the students spend on the electronic media.

Block (2008) concurs that excessive use of internet by adolescents leads to wastage of time lying and feelings of depression. The results agree with those of Yahaya et al. (2010) who established that most of the truant students wasted their time on entertainment at home leading to their misbehavior at school. However, the results contradict those of Cotton and Wikelund (2001) who argued that parents can influence their children's behavior through guiding the children to manage their social and academic time wisely.

The results also revealed that time spent by students on internet at home downloading movies, music and chatting distracts their attention from 
studies as indicated by a mean score of 3.9 and by majority of the head teachers $(81.5 \%)$. These results indicate that although important information with educational content could be obtained online, parents should control students' exposure to the internet due to its negative effects. Igbokwe, Obidike and Ezeji (2012) agree that availability of the electronic media gadgets in the students' homes and lack of proper attention by parents distract students' attention from their studies. However, Murunga, Kilaha and Wanyonyi (2013) stated that electronic media has enabled people to share information throughout the world through connectivity and networking.

The findings further indicated that the head teachers were of the view that parents' control of exposure to electronic media enhances discipline with the item posting a mean score of 3.9 and the majority (77.1 $\%)$ of the school principals agreeing with the statement. The results indicate that the students' lack of parental guidance on selection of the content to access from the electronic media leads to their misbehavior hence the need for parental involvement in regulation of students' discipline cannot be overemphasized. Yahaya et al (2010) concur that parents should control their children's social life to prevent them from acquiring negative behavior which is manifested in school. However, the results contradict the Children's Act Article 23, Section $2 \mathrm{c}$ (i) which provide that it is the responsibility of the parents to guide their children's behavior (Republic of Kenya, 2001).

\section{Level of students' discipline}

It was established that the level of students' discipline in schools was low as indicated by the majority (64.3\%) of the head teacher and slightly more than half $(53.7 \%)$ of the class teachers. The results indicate that students' limitless exposure to electronic media in their homes had a negative impact on their behavior at school. Westling (2010) concurs that students' indiscipline is the main concern of educators in public day secondary schools today.

\section{Students' use of the electronic media when at home}

The results revealed that most of the students spent 2-5 hours daily using the internet or watching television when they are at home as indicated by $50.6 \%$ percent of the students while only $17.2 \%$ of them stated that they spent less than one hour on electronic media daily. These results corresponded with the responses from the focus group discussions that students have uncontrolled exposure to the electronic media facilities in their homes which negatively affect their discipline. However, $16 \%$ of the students indicated that they had no access to electronic media facilities when they were at home. This finding confirmed the responses of focus group 
discussions that some of the students were not exposed to electronic media facilities at home because their parents could not afford to buy the electronic gadgets due to poverty. Murunga, Kilaha \& Wanyonyi, (2013) concur that high levels of poverty in Kenya hinder access and use of ICT facilities.

\section{Strategies that could be used by parents to control students' use of electronic media}

The findings showed that parents should control the time students spent on electronic media for entertainment as indicated by a mean score of 4.2 and by majority of the head teachers $(81.5 \%)$. The results indicate that parents' control of the time students spend on electronic media for entertainment at home can help to improve the students' behavior at school. The results indicate that control of students' time spent on electronic media for entertainment at home would enable them to avoid copying negative behavior, concentrate on their studies and complete their homework. Igbokwe, Obidike and Ezeji (2012) concur that availability of electronic devices make students to waste time when they watch programs on television and websites on the internet without any educational content. However, Nyamusana (2010) disagrees that parental involvement in the management of students' discipline improves the students discipline in schools.

The head teachers also suggested that parents should avoid students' exposure to electronic media violence in the television as indicated by 81.4 percent. The statement elicited a mean score of 4.1. The results imply that avoidance of students' exposure to electronic media violence in the television can help to improve students' discipline at school. Saleem and Anderson (2012) concur that students' exposure to some violent television programs accessed at home influence them to engage in violent behaviors leading to insecurity in schools. Poipoi, Agak and Kabuka (2011) agree that concerted effort is needed from parents and teachers to control cases of violent behavior in schools.

The head teachers further indicated that parents should restrict the content accessed by students from the internet sites as indicated by the majority $(81.5 \%)$. The statement posted a mean score of 4.1 . The results indicate that parents' restriction of the content accessed by students from the internet sites can help to improve students' behavior at school. Kirui, Mbugua and Sang (2011) concur that some of the violent television programs cause insecurity in schools as the children practice what they observe. However, John (2013) disagree that all media content accessed by students is bad.

It was also established that parents should educate their children about the unrealistic acts observed in media as indicated by the highest proportion $(74.3 \%)$ of the head teachers. The item elicited a mean score of 
3.9. The results indicate that education of students about unrealistic acts observed in media can help to improve students' discipline. Nabavi (2012) concurs that children become more aggressive when they observe violent models. Mahmud (2014) agrees that parents should help school managers to overcome discipline problems by giving proper advice to their children to practice core moral values in school.

Cross tabulation between students' exposure to electronic media and their discipline showed that the students who were highly exposed to electronic media facilities in their homes had low level of discipline as indicated by the majority (60\%) of the head teachers. On the contrary, $58 \%$ of the principals indicated that the students who had not been exposed to electronic media were highly disciplined. The results indicate that the students' indiscipline was caused by their uncontrolled access to negative information from the electronic media which influenced their behavior negatively. Lauer (2013) concurs that prolonged technology use by students is associated with their discipline problems. Onderi and Makori (2013) agree that students' exposure to electronic media violence at home leads to violence in secondary schools.

The results of One Way Analysis of ANOVA indicated that the Pvalue $=0.087$ which is more than the significant level of 0.05 . On this basis, the hypothesis was accepted and conclusion was made that there is no significant difference in means between parents' exposure of students to electronic media facilities and parental involvement in management of students' discipline in public day secondary schools. This finding implies that students' exposure to electronic media facilities at home may not significantly influence their discipline.

The finding also implies that not all students in the study area were able to access the electronic media facilities in their homes since their parents were too poor to afford the cost of electronic gadgets. Moreover, most of the day scholars commuted from rural areas where there was no electricity or internet connectivity. These factors hundred the students from accessing the electronic media facilities which could have adversely influenced their behavior. The finding concurs with Pearson (2006) who observed that negative media influence alone is not enough to account for students' indiscipline at school. It also concurs with Lavin, Korte and Davies (2010) who asserted that when used appropriately, technology can have a positive impact on students' behavior and perceptions, amount of time they study for exams and their overall attendance to class.

\section{Conclusion}

It was concluded that acquisition of negative information from electronic media facilities at home promote students' indiscipline in school. 
Students who were highly exposed to electronic media facilities in their homes had low level of discipline. Parents' exposure of students to electronic media facilities influenced parental involvement in management of students' discipline although this was not significant. Majority of the school principals and class teachers in public day secondary schools were male. Most of the head teachers had a working experience of more than 15 years while majority of the class teachers had worked for less than five years.

\section{RECOMMENDATIONS}

The parents should:

i.Stop exposing students to electronic media violence in the television.

ii.Control the time students spent on electronic media for entertainment at home.

iii.Use passwords to restrict the content accessed by students from some television channels and internet sites.

iv.Educate their children about the unrealistic acts observed in media.

The Teachers Service Commission should increase the appointment of female head teachers to act as role models for girls.

Schools should increase appointment of female class teachers to manage students' behavior.

\section{Recommendation for further research}

A study should be carried out on effectiveness of parental involvement in controlling students' exposure to electronic media in public boarding secondary schools in Kenya.

\section{References:}

1. Anderson, C. A., Berkowitz, L., Donnerstein, E., Huesmann, L. R., Johnson, J. D., Linz, D., Malamuth, N. M. \& Wartella, E. (2003). The Influence of Media Violence on Youth. Psychological Science in the Public Interest, 4(3): 81-110. Available @ https://www.mtholyoke.edu. Accessed 22/8/2017.

2. Block, J. L. (2008). Issues for DSM-V: Internet addiction. American Journal of Psychiatry, 165(3): 306-307. Available @ https://www.ncbinlm.nih.gov. Accessed 16/8/2016.

3. Bosire, J. Sang, A. K. Kiumi, J. K. \& Mungai, V. C. (2009). Relationship between principal' managerial approaches and student discipline in secondary schools in Kenya. African Research Review. An International Multi-Disciplinary Journal. Ethiopia 3 (3): 399-413. ISSN 2070-0083 (Online). Available @www.afrrevjo.net. Accessed 13/6/2016. 
4. Cotton, K. \& Wikelund, K. R. (2001). Parent involvement in education.Available@http://www.nwrel.orglcomm/resources.html. Accessed 30/12/2013.

5. Esther, T. \& Cheng, Y. (1999). Discipline Problems in Schools as Perceived by Teachers. Singapore: Institute of Education. Teaching and Learning, 19(2): 1-12. Available @ https: respository.nie.edu.sg. Accessed 24/12/2016.

6. Gould, C. \& Ward C. L. (2015). Positive Parenting in South Africa. Why Supporting Families is Key to Development and Violence Prevention. Institute for Security Studies Policy Brief. www.issafrica.org.

7. Igbokwe, J. C., Obidike, N. A. and Ezeji, E. C. (2012). Influence of Electronic Media on Reading Ability of School Children. University of Nigeria, Nsukka, Nigeria. Available from: athttp://unllib.unl.edu/LPP/ISSN 1522-0222. Accessed on 30/12/2013.

8. Ilomäki, L. (2008). The effects of ICT on School: Teachers' and Students' perspectives. Doctoral thesis. University of Turku, Finland.

9. John, N. R. (2013). Influence of Electronic Media on Behavior among Secondary School Students in Mukaa District, Makueni County, Kenya. master of education Unpublished Masters Thesis. Catholic University of Eastern Africa Kenya.

10. Khewu, P.D.N. (2012). A study of practices in the alternatives to corporal punishment Strategy being implemented in selected primary schools in buffalo city metro municipality: implications for school leadership. PhD Dissertation. University of Fort hare.

11. Kilonzo, J. (2013). Challenges Faced by Head Teachers in the Management of Students' Indiscipline in Public Secondary Schools in Lamu County. Unpublished M. ED Research Project, Kenyatta University.

12. Kirui, R. K, Mbugua, Z. K \& Sang, A. K. (2011). Challenges Facing Head teachers in Security Management in Public Secondary Schools in Kisii County, Kenya. International Journal of Humanities and Social Science 1(15): 228-233 (Special Issue - October 2011). Available @ www.ijhssnet.com. Accessed 2 May 2016.

13. Lauer, J. (2013). Disconnect to connect: Balancing the Use of Technology in our Lives. Unpublished Masters Project. Winona State University.

14. Light. D. (2009). The Role of ICT in Enhancing Education in Developing Countries: Findings from an Evaluation of The Intel ${ }^{\circledR}$ Teach Essentials Course in India, Turkey and Chile. EDC/Center for Children and Technology. 
15. Lin, T.C. \& Pao, T. P. (2011). Leisure Activities Selection and Motivation. International Journal of Academic Research in Business and Social Sciences 1(3):308-320. ISSN: 2222-6990. Available @ www.hrmars.com/journals. Accessed on 13 June 2013.

16. Mahmud, M. Z. (2014). Leadership and Management School in Controlling Discipline. Journal of Education and Practice 5(23):128131. Available from: http://www.iiste.org. Accessed 25 June 2016.

17. Mugenda, O. \& Mugenda, A. (2003). Research Methods, Quantitative and Qualitative Approaches. Nairobi: ACTS.

18. Murunga, F., Kilaha, K. \& Wanyonyi, D. (2013). Emerging Issues in Secondary School Education in Kenya. International journal of advanced research 1 (3):231-240. Available @ http://www.journalijar.com. Accessed on 2/5/2016.

19. Nabavi, R. T. (2012). Bandura's Social Learning Theory and Social Cognitive Learning Theory. University of Science and Culture. Available from: Razieh Tadayon Nabavi. Retrieved on: 24 June 2016.

20. Nyamusana, G. (2010). Influence of Parents' Participation in Secondary School Management on Students' Academic Performance in Buyaga County Kibaale District. Unpublished MED Research Dissertation. Makerere University.

21. Omangi, D. (2016, August $5^{\text {th }}$ ). School Fires Are a Mirror of Society. Nairobi. Nation Media Group.

22. Onderi, H. \& Makori, A. (2013). Secondary School Principals in Nyamira County, in Kenya: Issues and Challenges. Educational Research International 1(1):67-90. Available @ www.journals.savap.org.pk. Accessed on 20/8/2015.

23. Pearson, A. D. (2006). Media Influence on Deviant Behavior in Middle School Students. A Masters Thesis. University of North Carolina, Wilmington.

24. Lavin, A. M., Korte, L. \& Davies T. L. (2010). The impact of classroom technology on student behavior. Journal of Technology Research, 2(1):1-13. Available @ www.scirp.com. Accessed on 24/8/2017.

25. Light. D. (2009). The Role of ICT in Enhancing Education in Developing Countries: Findings from an Evaluation of The Intel ${ }^{\circledR}$ Teach Essentials Course in India, Turkey and Chile. EDC/Center for Children and Technology.

26. Poipoi, M. W., Agak, J. O. \& Kabuka, E. K. (2011). Perceived Home Factors Contributing to Violent Behavior Among Public Secondary School Students in Western Province, Kenya. Journal of Emerging Trends in Education Research and Policy Studies, 2(1): 30-40. ISSN: 
2141-6990. Available @ jeteraps.scholarlinkresearch.org Accessed 3/3/2011. Republic of Kenya. (2001). Children's Act 8 of 2001. Nairobi: Government Printers.

27. Republic of Kenya. (2001). Children's Act 8 of 2001. Nairobi: Government Printers.

28. Republic of Kenya (2006 b), Revised 2014. Code of Regulations. Nairobi: Ministry of State for Public Service.

29. Republic of Kenya. (2007 a). Gender policy in education. Nairobi: Ministry of Education.

30. Republic of Kenya. (2010). The Constitution of Kenyan, 2010. Nairobi: Government Printer.

31. Saleem, M. \& Anderson, C. A. (2012). The Good, the Bad and the Ugly of Electronic Media. Chapter in Dvoskin, J., Skeem, J. L., Novaco, R. W., \& Douglas, K. S. (Eds.). Using Social Science to Reduce Violent Offending. (pp. 83-101). New York: Oxford University Press.

32. Stewart, D. (2004). Learner discipline: An Australian Perspective. Sydney: Pearson Education.

33. Tayie, S., Jacquinot-Delaunay, G., Carlsson, U., \& Tornero, J. M. P. (2008). Empowerment through Media Education. An Intercultural Approach. The International Clearing house on Children, Youth and Media. Nordicom, Göteborg University. Available @ revistacomsoc.pt. Accessed on 7/7/2015.

34. Wango, G. M., Musomi, M, and Akinyi, C. (2012). Gender and Education in Kenya and Re-Alignment of Education to the Constitution. Nairobi: ITP Human Rights Towards Gender Equality Seminar. Accessed 11 October 2016.

35. Westling, D. L. (2010). Teachers and Challenging Behavior: Knowledge, Views, and Practices. Remedial and Special Education, 31(1): 48-63. Journals.sagepub.com. Accessed on 16/8/2017.

36. Yahaya, A., Ramli, J., Hashim, S., Ibrahim, M. A., Kadir, H. A., Boon, Y. \& Rahman, R. R. A. (2010). The Effects of Various Modes of Absenteeism Problem in School on the Academic Performance of Students in Secondary Schools. European Journal of Social Sciences, 12 (4): 624-639. Accessed on 2/5/2016 